\title{
Smart Sterilization System pada Ruang Kelas Berbasis UVC
}

\author{
A. Z. N. Azza' ${ }^{1}$ D. F. Amal ${ }^{1}$, F. R. Pinestiti ${ }^{1}$, N. N. Alfian', S. Safiinatunnajah ${ }^{1}$, D. J. Suroso ${ }^{1}$ \\ ${ }^{1}$ Jurusan Teknik Fisika, Fakultas Teknik, Universitas Gadjah Mada \\ \{annisa.z.n, dawam.f.a, farrastikarey2018, ndarunuridho99, syifaa\}@mail.ugm.ac.id, dwi.jokosuroso@ugm.ac.id
}

\begin{abstract}
Abstrak
Jumlah terkonfirmasi positif Coronavirus Disease 2019 (Covid-19) di Indonesia sejak 2 Maret 2020 hingga 16 April 2021 telah mencapai 1.594.722 jiwa, di mana 43.196 jiwa di antaranya meninggal dunia. Covid-19 disebabkan oleh Severe Acute Respiratory Syndrome Coronavirus-2 yang menyebar secara cepat melalui droplet dan viabel pada kondisi tertentu. Di sisi lain, Kementerian Pendidikan dan Kebudayaan Republik Indonesia berencana mengizinkan perkuliahan tatap muka yang dimulai pada Juli 2021. Tentunya kebijakan tersebut menuntut protokol kesehatan yang ketat serta fasilitas yang menunjang kegiatan pembelajaran agar mencegah penularan Covid-19. Oleh sebab itu, pada penulisan ini dirancang suatu inovasi berupa smart classroom yang terdiri atas sistem sterilisasi berbasis sinar ultraviolet C (UVC) dengan panjang gelombang $254 \mathrm{~nm}$. Smart classroom juga dilengkapi dengan sistem keamanaan berupa pengunci otomatis, contactless sensor untuk membuka dan menutup pintu, pencahayaan otomatis, dan sistem monitoring berbasis Internet of Things (IoT) secara real-time. Pada penulisan ini dilakukan simulasi dengan menggunakan Tinkercad dan web server Thingspeak. Proses sterilisasi dirancang untuk dilakukan selama 30 menit dengan dosis UVC sebesar $220 \mathrm{~J} / \mathrm{m}^{2}$. Untuk ruang kelas dengan luas lantai 64,08 $\mathrm{m}^{2}$, dibutuhkan dosis sebesar 14.097,6 J sehingga dibutuhkan 2 buah lampu Philips UVC bertipe TMS030-1x-Tubular Ultraviolet (TUV)-T8-18W-High Frequency Performer (HFP) yang memiliki iradiasi sebesar $0,09 \mathrm{~W} / \mathrm{m}^{2}$.
\end{abstract}

Kata kunci : Covid-19, IoT, ruang kelas, sterilisasi, UVC

\section{Pendahuluan}

Indonesia pertama kali mengumumkan kasus positif Coronavirus Disease 2019 (Covid-19) pada tanggal 2 Maret 2020, yakni sebanyak 2 kasus (WHO, 2020). Covid-19 merupakan penyakit yang disebabkan oleh Severe Acute Respiratory Syndrome Coronavirus-2 (SARS-CoV-2) (Susilo et al., 2020). Penyakit tersebut terus menyebar dan sampai pada tanggal 16 April 2021 jumlah terkonfirmasi positif Covid-19 menunjukkan angka 1.594.722 jiwa di mana 43.196 jiwa di antaranya meninggal dunia (GTPPC19, 2021). Jumlah tersebut menjadikan Indonesia sebagai negara dengan kasus terkonfirmasi positif Covid-19 terbanyak ke-4 di Asia dan ke-19 di dunia (Worldometer, 2021).

Penyebaran SARS-CoV-2 terjadi secara cepat antara manusia dengan manusia lainnya dan menjadi sumber transmisi yang utama. Penularan tersebut dapat terjadi melalui droplet yang dikeluarkan pada saat batuk atau bersin dari seseorang yang terinfeksi virus tersebut (Susilo et al., 2020). SARS-CoV-2 mampu bertahan hidup pada aerosol selama kurang lebih 3 jam (Susilo et al., 2020). Oleh karena itu, pembatasan berbagai aktivitas dilakukan untuk mencegah penularan virus tersebut.

Salah satu aktivitas yang sangat terdampak yaitu aktivitas belajar mengajar di mana proses yang dilakukan berubah dari luring menjadi daring. Kementerian Pendidikan dan Kebudayaan Republik Indonesia berencana mengizinkan perkuliahan tatap muka di perguruan tinggi yang akan dimulai pada Juli
2021 (Kompas, 2021). Perkuliahan tatap muka tersebut dilakukan dengan tetap menerapkan protokol kesehatan guna mencegah penyebaran Covid-19. Selain penerapan protokol kesehatan, upaya-upaya lainnya juga diperlukan seperti dengan menyediakan suatu sistem atau fasilitas yang menunjang guna mengoptimalkan proses belajar mengajar secara tatap muka.

SARS-CoV-2 mampu bertahan hidup di suatu material selama beberapa waktu tertentu tergantung dari jenis material tersebut. Oleh karena itu, diperlukan suatu fasilitas sterilisasi yang dapat menginaktivasi virus guna mencegah penyebarannya. Selama ini terdapat beberapa metode sterilisasi yang dilakukan, seperti sterilisasi dengan disinfektan, pemanasan, dan sinar ultraviolet (UV) (Darnell et al., 2004). Di antara metode-metode tersebut, metode penyinaran UV menjadi metode yang cukup efektif (Chitnis et al., 2008).

Berdasarkan penelitian yang dilakukan oleh Ika (Arinda, 2015) didapatkan hasil bahwa daya lampu dan lama penyinaran UVC berpengaruh nyata terhadap jumlah mikroba serta warna sari buah salak pondoh. Hasil optimal diperoleh dengan daya lampu 60Watt dan lama penyinaran 50 menit. Penelitian tersebut hanya meneliti dampaknya pada suatu sel mikroba, bukan virus, sehingga perlakuan atau efek terhadap suatu virus belum bisa diketahui.

Sementara itu, menurut penelitian lain yang dilakukan oleh Bianco dan kawan-kawan (Bianco et al., 2020) menunjukkan suatu hasil bahwa radiasi UVC dapat menginaktivasi SARS-CoV-2 tergantung dari 
dosis radiasi dan konsentrasi virus tersebut. Berdasarkan penelitiannya, dosis UVC $<4 \mathrm{~mJ} / \mathrm{cm}^{2}$ dapat digunakan untuk sterilisasi ruangan tertutup dengan level kontaminasi yang rendah. Sementara itu, dosis UVC $\geq 16,9 \mathrm{~mJ} / \mathrm{cm}^{2}$ dapat digunakan untuk menginaktivasi virus dengan konsentrasi virus yang tinggi, seperti 1000 Multiplicity of Infection (MOI). Melalui penelitian yang dilakukan Cahyo dan Kurniawan (Muvianto \& Yuniarto, 2020), diketahui bahwa sinar UVC juga dapat didesain sebagai disinfectant chamber alat pelindung diri (APD) pegawai rumah sakit untuk mengurangi risiko proses pencucian yang berulang. Paparan sinar yang diberikan memiliki dosis sebesar $67 \mathrm{~J} / \mathrm{m}^{2}$ dengan lama penyinaran minimal 15 menit.

Hasil penelitian sebelumnya semakin dikuatkan oleh penelitian Reza S. R. dan Ika N. A. (Rinaldi \& Anggraini, 2021) pada perancangan sistem disinfektan UVC untuk sterilisasi paket pada jasa pengiriman barang sebagai upaya pencegahan Covid-19. Penelitian tersebut menunjukkan suatu hasil bahwa sistem disinfektan UVC yang dirancang mampu membunuh virus corona hingga 90\% dengan lama waktu paparan UVC terhadap paket tersebut dalam area sterilisasi minimal selama 16 detik. Sinar UVC tersebut juga dapat diaplikasikan dalam penanganan wabah Covid19 di rumah sakit.

Selanjutnya dari segi sistem kendali, pada penelitian lain diketahui telah mampu menghasilkan sistem kendali yang memenuhi faktor keamanan dan kepraktisan untuk mengendalikan alat sterilisasi ruangan menggunakan lampu UVC $254 \mathrm{~nm}$. Alat tersebut dikendalikan dengan bantuan tiga sensor PIR dengan total cakupan area 360 derajat di mana dapat mendeteksi keberadaan manusia dan binatang dengan jarak maksimal 7 meter. Selain itu, tersedia fitur penjadwalan dan penghitung masa pemakaian lampu UVC yang berjalan dengan baik (Pristianto et al., 2020).

Dengan demikian, pada penulisan ini akan dijelaskan suatu inovasi, berupa smart classroom yang terdiri dari sistem sterilisasi dengan sinar UVC guna mendukung kegiatan pembelajaran tatap muka di era new normal. Rancangan smart classroom tersebut juga dilengkapi dengan sistem pengendali untuk keamanaan berupa pengunci otomatis, contactless sensor untuk membuka dan menutup pintu, pencahayaan otomatis, dan sistem monitoring berbasis Internet of Things (IoT).

\section{Tinjauan Pustaka}

\subsection{Karakteristik Covid-19}

SARS-CoV-2 merupakan virus yang dapat menyebar ke dalam tubuh manusia dan menular. Masa inkubasinya sekitar 3-7 hari setelah masuk ke dalam tubuh manusia, atau bahkan hingga mencapai 14 hari (Prastyowati, 2020). Selama kurun waktu tersebut, ketika pasien melakukan kontak dekat dalam waktu yang lama dengan jarak sekitar 1 meter, mereka dapat dengan mudah menyebarkan virus kepada manusia lain.

Penularan dapat terjadi secara langsung melalui droplet pernapasan yang mengandung virus dan secara tidak langsung melalui kontak dengan benda yang terkena droplet tersebut (Prastyowati, 2020). Droplet saluran napas berdiameter > 5-10 $\mu \mathrm{m}$, sementara droplet yang berdiameter $\leq 5 \mu \mathrm{m}$ disebut sebagai droplet nuclei atau aerosol (WHO, 2020). Penyebaran droplet nuclei (aerosol) ini bisa terjadi dengan melayang di udara lalu bergerak sampai jarak yang jauh, atau biasa dikenal dengan transmisi udara (airborne) (Prastyowati, 2020).

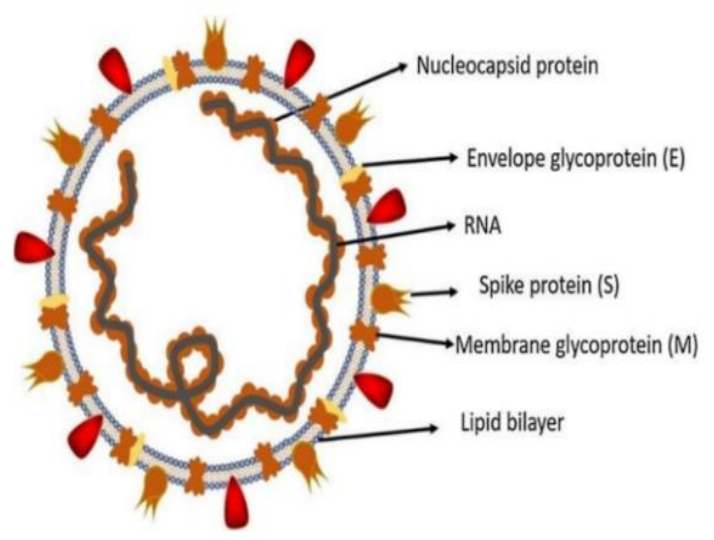

Gambar 1. Strukur corona (Shereen et al., 2020)

Salah satu penelitian menurut pakar epidemiologi penyakit menular Universitas Gadjah Mada (UGM), Dr. Hari Kusnanto Josef (Hari Kusnanto Josef) menunjukkan bahwa SARS-CoV-2 rata-rata mampu bertahan hidup di udara hanya dalam waktu setengah jam. Tidak seperti ketika berada di permukaan benda yang bisa bertahan hidup berhari-hari (Ika, 2020). Penelitian lain juga menemukan hasil bahwa virus Covid-19 tetap viabel dalam rentang waktu yang berbeda bergantung mediumnya, seperti 1 hari pada kain dan kayu, 2 hari kaca, 4 hari pada stainless steel dan plastik, 7 hari pada lapisan luar masker medis (WHO, 2020).

Virus Covid-19 juga dapat bertahan hidup pada berbagai rentang nilai $\mathrm{pH}$ dan suhu lingkungan, tetapi rentan terhadap panas dan metode disinfeksi atau sterilisasi standar (WHO, 2020). Transmisi virus Covid-19 sendiri terkait erat dengan kontak dekat antar manusia di tempat yang tertutup (seperti rumah, fasilitas medis, dan institusi tempat tinggal). Selain itu, di perkantoran, tempat ibadah, pasar, transportasi, sekolah, kampus, dan tempat-tempat yang secara umum dapat dijangkau, diketahui bahwa penularan Covid-19 mudah terjadi (WHO, 2020).

\subsection{Sterilisasi}

Salah satu cara yang dapat dilakukan dalam upaya mengurangi penularan dari virus ini yaitu dengan 
menjaga kebersihan diri, seperti cuci tangan pakai sabun (CTPS) dan penggunaan masker ketika keluar rumah yang terus digaungkan oleh pemerintah (Dwi Elisanti \& Ardianto, 2020). Namun, CTPS sendiri tidak dapat dipraktikkan dalam kondisi tertentu. Oleh karena itu, muncul beberapa inovasi untuk menggantikan fungsi CTPS, salah satunya yaitu metode sterilisasi (Dwi Elisanti \& Ardianto, 2020). Dalam pengertian medis, sterilisasi adalah suatu proses yang dapat memberikan hasil akhir berupa keadaan yang tidak dapat lagi ditemukan mikroorganisme, dengan sebuah metode tertentu (Raudah et al., 2017). Di dalam dan luar negeri, beberapa produk sterilisasi untuk meminimalisasi Covid-19 menggunakan sinar ultraviolet, beberapa produsen telah mengklaim bahwa sinar ultraviolet dapat membunuh virus dan bakteri (Dwi Elisanti \& Ardianto, 2020). Bahan lain yang biasa digunakan untuk sterilisasi adalah bahan kimia, seperti alkohol, klorin, dan natrium hipoklorit (WHO, 2020).

\subsection{Sinar Ultraviolet}

Sinar ultraviolet (UV) adalah radiasi elektromagnetis yang memiliki panjang gelombang di antara sinar $\mathrm{X}$ dan sinar tampak, yaitu berada dalam rentang 100-400 nm (Cahyonugroho \& Hendriyanto, 2011). Sinar ini dihasilkan oleh matahari dan tidak dapat dilihat oleh mata manusia (Isfardiyana \& Safitri, 2014). Ditinjau dari panjang gelombangnya, sinar ultraviolet dapat digolongkan dalam tiga jenis, yaitu ultraviolet C (UVC) atau gelombang pendek (short wave) yang memiliki panjang gelombang 100-280 nm, ultraviolet B (UVB) atau gelombang medium (medium wave) yang memiliki panjang gelombang 280-315 nm, dan ultraviolet A (UVA) atau gelombang panjang (black light) yang memiliki panjang gelombang 315$400 \mathrm{~nm}$ (Seran et al., 2018). Penggunaan sinar ini perlu diperhatikan karena jika terkena tubuh manusia terlalu lama, paparan sinarnya baik UVA, UVB, maupun UVC dapat menimbulkan dampak negatif berupa kemerahan pada kulit, kulit terasa terbakar, katarak, eritema, kerut pada kulit, hingga kanker kulit (Isfardiyana \& Safitri, 2014). Di sisi lain, sinar UV memiliki manfaat yang beragam bagi manusia. Sinar ini dapat digunakan untuk mensintesis vitamin $\mathrm{D}$, membantu pengobatan penyakit psoriasis (Isfardiyana \& Safitri, 2014), dan berfungsi sebagai agen germicidal (Muvianto \& Yuniarto, 2020), yaitu kemampuan membunuh bakteri.

\subsection{Sinar Ultraviolet $\mathrm{C}$}

Keefektifan sinar UV dalam membunuh bakteri mulai dipublikasikan pada tahun 1877 ketika dua ilmuwan Inggris menemukan bahwa larutan Pasteur dalam tabung reaksi yang dilapisi timbal akan menumbuhkan bakteri yang tidak terhitung, sedangkan larutan Pasteur yang tidak tertutup dan diletakkan di bawah sinar matahari tidak menumbuhkan bakteri di dalamnya (Lee, 2017). Namun, masing-masing jenis sinar ultraviolet memiliki kemampuan yang berbeda dalam menjalankan fungsi sebagai agen germicidal. Radiasi sinar UV yang dibutuhkan untuk membunuh bakteri berada dalam rentang panjang gelombang sinar UVC, yaitu 220-290 nm. Pada rentang tersebut, nilai yang paling efektif adalah pada panjang gelombang 254 nm (Yulianto et al., 2019). Absorpsi sinar UV tersebut dapat menyebabkan mutasi sel (Yulianto et al., 2019) serta kematian agen biologis seperti mikroba dan virus (Muvianto \& Yuniarto, 2020).

Ribonucleic acid (RNA) dan deoxyribonucleic acid (DNA) virus dapat menyerap sinar UVC dengan panjang gelombang $254 \mathrm{~nm}$ secara baik sehingga menyebabkan kerusakan pada sel. Sinar UVB juga dapat menyebabkan kerusakan, namun 20-100 kali lipat kurang efisien daripada UVC. Sementara itu, sinar UVA jauh kurang efektif dibandingkan UVB dan UVC karena diserap dengan lemah oleh RNA dan DNA (Darnell et al., 2004). Hal tersebut menunjukkan bahwa sinar UVC merupakan jenis sinar UV yang paling efektif dalam membunuh bakteri atau virus. Tidak hanya pada permukaan benda, sinar UVC juga efektif dalam mengurangi jumlah bakteri yang beredar di udara (Lee, 2017).

Pemanfaatan lampu UVC untuk sterilisasi ruangan telah banyak diterapkan terutama pada disinfeksi ruang operasi di dunia medis. Namun, tentunya pemilihan lampu UVC disesuaikan dengan kondisi objek yang ingin disterilisasi. Salah satu jenis lampu UVC yang dapat digunakan adalah Pulsed Xenon UVC (PXUVC). Lampu PX-UVC memancarkan pulsa spektrum cahaya yang meliputi sinar UVC (100-280 nm) dan sinar tampak (380-700 nm) (Casini et al., 2019). Pulsa yang dipancarkan memiliki intensitas tinggi dan memungkinkan durasi pancaran yang lebih rendah, yaitu 15-20 menit. Namun, PX-UVC dinilai kurang efektif dibandingkan jenis lampu yang pancarannya bersifat continuous (Spencer et al., 2017), seperti low pressure lamp. Low pressure lamp merupakan salah satu sumber UVC yang paling efisien di mana 35\% dari input watt diubah menjadi watt UVC. Jenis ini telah banyak digunakan pada disinfeksi ruangan karena lampu yang beredar secara komersial memiliki karakteristik panjang gelombang $254 \mathrm{~nm}$ (Philips, 2006).

\subsection{Sistem Otomasi}

Sistem otomasi dalam penggantian peran manusia pada suatu proses dapat didefiniskan sebagai gabungan atau integrasi dari mekanika, sistem kelistrikan, dan sistem komputer. Otomasi dapat bekerja secara berulang-ulang dan tidak dilakukan oleh manusia (Fauzan, 2015). Ada beberapa pendekatan yang digunakan dalam penerapan sistem otomasi, salah satunya adalah pendekatan The USA Principle (Hakim et al., 2017):

1. Understand the Existing Process 
Tahap pertama, suatu proses harus dipahami dengan baik dan teliti. Mulai dari masukan, tahap proses, keluaran yang terjadi di antara masukan dan keluaran, serta fungsi dari setiap proses.

2. Simplify the Process

Setelah proses awal dipahami dengan baik, langkah selanjutnya adalah menyederhanakan proses. Proses awal akan dikaji lebih lanjut tentang fungsi dari proses tersebut.

3. Automate the Process

Langkah terakhir adalah penerapan otomasi pada proses tersebut.

Adapun tuntutan perancangan untuk komponenkomponen pada sistem otomasi yang digunakan yakni sebagai berikut:

1. Desain atau ukuran komponen yang relatif kecil (ergonomis) karena akan ditempatkan secara indoor pada suatu ruang kelas.

2. Komponen memiliki ketahanan material yang kuat agar dapat tahan lama.

3. Sensor Passive Infrared (PIR) memiliki sensitivitas yang besar pada jarak kurang dari $20 \mathrm{~cm}$ karena dikhawatirkan benda lain pada jarak yang jauh akan ikut terdeteksi oleh sensor.

Tabel 1. Deskripsi komponen

\begin{tabular}{|c|c|}
\hline Komponen & Deskripsi \\
\hline Arduino & $\begin{array}{l}\text { Arduino adalah papan mikrokontroler } \\
\text { yang berfungsi untuk mengendalikan } \\
\text { berbagai jenis aktuator, motor, lampu, } \\
\text { dan lainnya (Suwantoro \& Samsugi, } \\
\text { 2018). Arduino yang digunakan ialah } \\
\text { Arduino Uno R3. }\end{array}$ \\
\hline Relay & $\begin{array}{l}\text { Relay merupakan sebuah komponen } \\
\text { yang berfungsi untuk menjalankan } \\
\text { setelan kontak saklar dengan } \\
\text { menggunakan } \\
\text { elektromagnetik } \\
\text { Hendriyani, 2019). }\end{array}$ \\
\hline $\begin{array}{l}\text { Sensor } \\
\text { Passive } \\
\text { Infrared }\end{array}$ & $\begin{array}{l}\text { Sensor Passive Infrared (PIR) } \\
\text { merupakan sebuah sensor yang } \\
\text { berfungsi untuk mendeteksi } \\
\text { keberadaan maupun gerakan objek } \\
\text { berdasarkan pancaran sinar infrared } \\
\text { pasif (Waworundeng et al., 2017). }\end{array}$ \\
\hline Motor DC & $\begin{array}{lrr}\text { Motor DC } & \text { sebagai } & \text { piranti } \\
\text { elektromekanik } & \text { dasar } & \text { yang } \\
\text { menggunakan } & \text { tegangan } & \text { searah } \\
\text { sebagai sumber tenaganya (Anuradha } \\
\text { et al., 2016). }\end{array}$ \\
\hline $\begin{array}{l}\text { Modul Wi- } \\
\text { Fi }\end{array}$ & $\begin{array}{l}\text { Modul Wi-Fi berfungsi sebagai } \\
\text { perangkat tambahan mikrokontroler } \\
\text { agar dapat terhubung dengan WiFi } \\
\text { dan membuat koneksi TCP/IP } \\
\text { (Iswanto \& Gandi, 2018). Modul Wi- } \\
\text { Fi yang digunakan ialah ESP8266. }\end{array}$ \\
\hline
\end{tabular}

\section{Metode}

Penulisan ini menggunakan metode pengambilan data berupa studi pustaka, yakni penulisan berdasarkan sumber-sumber terpercaya yang kemudian ditelaah, dikaji, diinterpretasikan, dan dituangkan dalam bentuk tulisan. Pengumpulan data dilakukan secara komprehensif dengan cara mengulas (review) berbagai artikel ilmiah yang membahas tentang sinar UV, Covid19, sistem sensor, sistem aktuator, sistem IoT, dan berbagai artikel ilmiah pendukung lainnya. Data-data yang didapatkan kemudian diolah sehingga menjadi landasan dalam perancangan smart sterilization system.

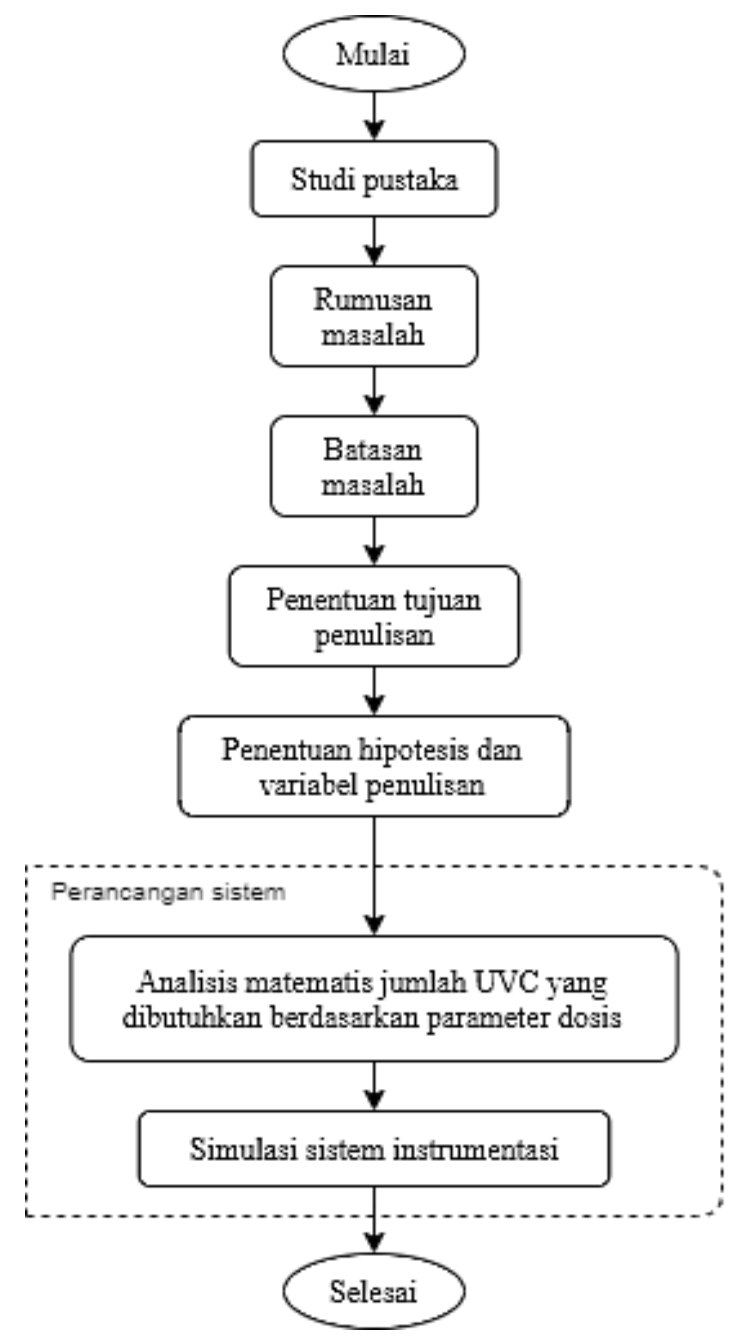

Gambar 2. Kerangka berpikir penulisan

Smart sterilization system dirancang untuk mempersiapkan ruang kelas yang menunjang kegiatan belajar mengajar (KBM) di era new normal dengan memanfaatkan sinar UV. Sinar UV sendiri memiliki tiga jenis, yakni UVA, UVB, dan UVC. Pemilihan jenis sinar UV yang akan digunakan menjadi sangat penting untuk diperhatikan karena ketiga jenis UV tersebut memiliki karakteristik dan panjang gelombang yang berbedabeda. Pada penulisan ini, jenis sinar UV yang dipilih yaitu UVC dengan panjang gelombang $254 \mathrm{~nm}$.

Perancangan smart sterilization system ini mengintegrasikan sinar UVC dengan sensor passive 
infrared (PIR) yang akan mengaktuasi penguncian pintu ruangan secara otomatis untuk memastikan bahwa tidak ada satu pun orang di dalam ruang kelas saat proses sterilisasi hendak dimulai. Rancangan sistem ini juga menggunakan sistem IoT sehingga mekanisme kerja sistem dan proses sterilisasi dapat terpantau dari jarak jauh.

Analisis pada penulisan ini terdiri atas analisis matematis jumlah UVC yang dibutuhkan agar memenuhi standardisasi dosis suatu ruangan saat new normal serta analisis sistem instrumentasi berupa simulasi sistem sensor, aktuator, dan IoT. Variabel yang berpengaruh pada analisis UVC adalah intensitas sinar UVC. Rancangan sistem ini juga memerlukan Standard Operating Procedure (SOP) yang menuntut pengguna kelas untuk patuh agar sistem berjalan lancar sehingga yang demikian menjadi batasan masalah pada penulisan ini. Kerangka berpikir penulisan ditunjukkan pada Gambar 2.

\section{Pembahasan}

\subsection{Deskripsi Objek}

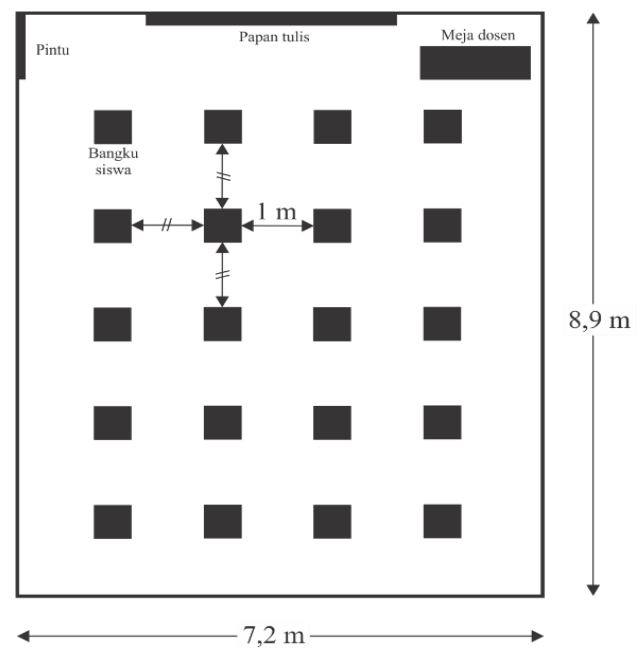

Gambar 3. Asumsi denah ruang kelas

Asumsi ruang kelas yang digunakan memiliki luas lantai $64,08 \mathrm{~m}^{2}$. Pada era normal baru setiap aktivitas yang melibatkan banyak orang setidaknya harus menjaga jarak 1meter antar orang. Begitu pula pada penataan tempat duduk di suatu ruang kelas harus diatur dengan sedemikian rupa sehingga bisa tetap mematuhi protokol kesehatan. Pengaturan tempat duduk dengan empat kursi dalam satu baris dan lima kursi dalam satu kolom sehingga total kursi pada ruang tersebut berjumlah 20 kursi.

\subsection{Mekanisme Sistem}

Diagram alir di bawah ini menjelaskan proses pengoperasian sistem sterilisasi sinar UV beserta sistem keamanan berupa pengunci otomatis, controller sensor, pencahayaan otomatis, dan sistem monitoring berbasis IoT.
Mekanisme diawali dengan lampu dihidupkan dan kunci dibuka sebelum kelas akan digunakan. Setelah kelas selesai digunakan, alarm diaktifkan selama 5 menit untuk mengingatkan orang yang berada di kelas supaya segera keluar dari kelas dan mengosongkan kelas. Setelah kelas kosong, pintu akan dikunci, UV dinyalakan, dan lampu dimatikan. Setelah semua sistem tersebut mati, proses sterilisasi UV akan berjalan selama 30 menit. Proses sterilisasi dijalankan saat pergantian kelas dengan jadwal kelas perhari berada pada Tabel 2., di mana pada setiap pergantian sesi dijeda 40 menit dengan 5 menit pertama untuk peringatan, 30 menit untuk sterilisasi, dan 5 menit sisanya sebagai waktu untuk memasuki kelas. Ketika kelas telah mencapai kelas terakhir di hari tersebut, maka kunci pintu tertutup, lampu mati, dan UV dimatikan. Namun, apabila kelas belum mencapai kelas terakhir pada hari tersebut maka siklus sistem berulang dari awal.

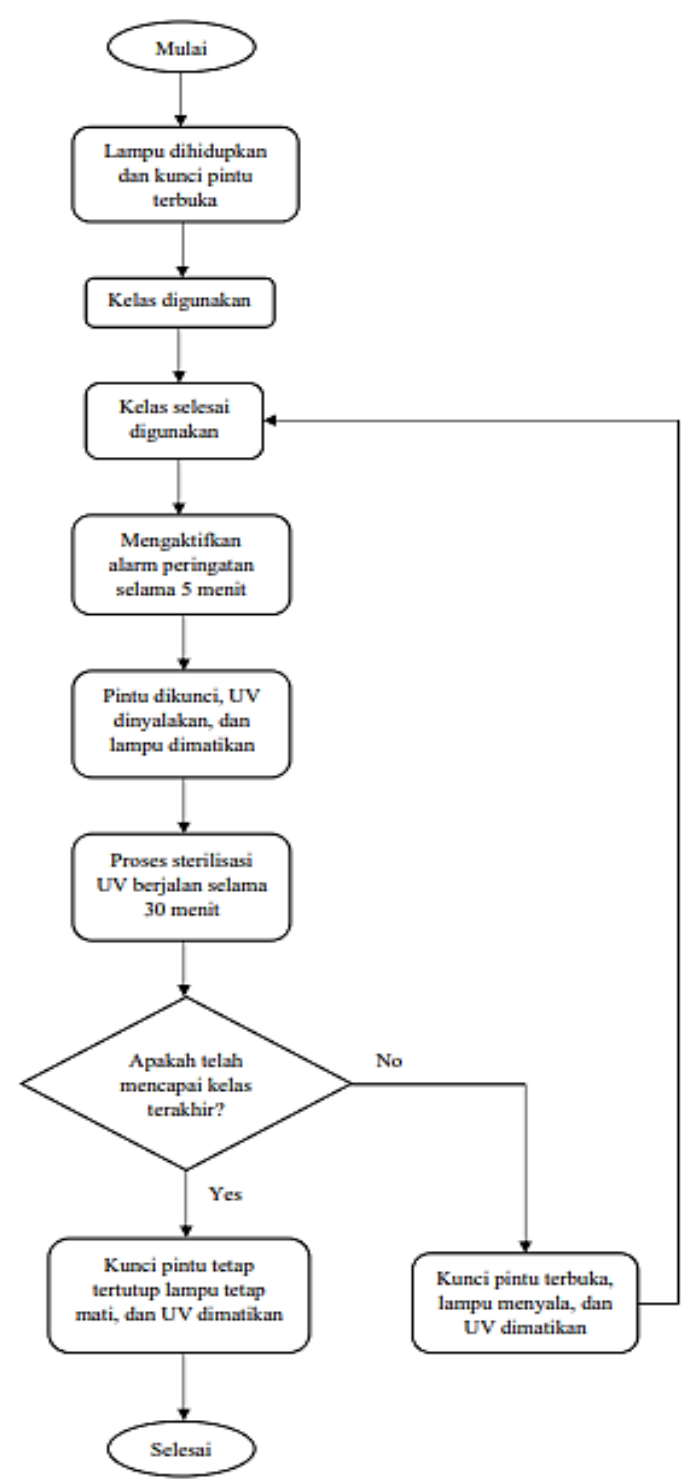

Gambar 4. Diagram alir mekanisme sistem 
Tabel 2. Aktivitas \& jadwal mekanisme sistem harian

\begin{tabular}{|c|c|}
\hline Waktu & Keterangan \\
\hline 06.50 & Aktivasi kelas \\
\hline $07.00-09.30$ & Kelas 3 SKS \\
\hline $09.30-10.10$ & Sterilisasi \\
\hline $10.10-11.50$ & Kelas 2 SKS \\
\hline $11.50-12.30$ & Sterilisasi \\
\hline $12.30-15.00$ & Kelas 3 SKS \\
\hline $15.00-15.40$ & Sterilisasi \\
\hline $15.40-17.20$ & Kelas 2 SKS \\
\hline $17.20-18.00$ & Sterilisasi \& deaktivasi kelas \\
\hline
\end{tabular}

Sistem akan beoperasi sesuai jadwal pada Tabel 2 .

Mulai pada pukul 06.50 dan selesai pada pukul 18.00. Jadwal tersebut berlaku setiap hari dengan total 10 satuan kredit semester (SKS)/hari dan dibagi menjadi 4 sesi. Pada setiap pergantian sesi dijeda 40 menit dengan 5 menit pertama untuk peringatan, 30 menit untuk sterilisasi, dan 5 menit pasca sterilisai sebagai waktu tunggu untuk memulai sesi kelas berikutnya.

\subsection{Analisis Dosis dan Jumlah Lampu}

Untuk mencapai tujuan sterilisasi ruangan, perancangan perlu mempertimbangkan pemilihan dosis lampu UVC. Sebuah percobaan laboratorium yang dilakukan oleh Dr. Anthony Griffiths dari Associate Professor of Microbiology di Boston University School of Medicine dan timnya menemukan bahwa sumber cahaya UVC dengan dosis UVC $5 \mathrm{~mJ} / \mathrm{cm}^{2}$ yang menyinari bahan yang diinokulasi virus SARS-CoV-2 mengurangi virus pada permukaan tersebut hingga $99 \%$, sedangkan dosis lampu UVC sebesar $22 \mathrm{~mJ} / \mathrm{cm}^{2}$ dapat mengurangi jumlah virus SARS-CoV-2 di permukaan benda hingga 99,9999\% (Philips, 2020). Untuk memaksimalkan disinfeksi ruangan maka perancangan ini menggunakan dosis lampu UVC sebanyak $22 \mathrm{~mJ} / \mathrm{cm}^{2}$. Pada dosis tersebut, salah satu produk yang telah beredar adalah Philips UVC bertipe TMS030-1x-TUV-T8-18W-HFP. Lampu tersebut memancarkan downward UVC irradiance sebesar 0,09 $\mathrm{W} / \mathrm{m}^{2}$ (Philips, 2020). Dari segi jenisnya, lampu tersebut termasuk ke dalam kategori low pressure lamp sehingga efektif untuk membasmi virus karena radiasinya berada pada panjang gelombang UVC paling efektif, yaitu $254 \mathrm{~nm}$ (Song et al., 2020).

Perancangan ini menganalisis jumlah lampu UVC yang akan diletakkan pada ruangan berdasarkan perhitungan yang ditunjukkan pada Tabel 3.

Tabel 3. Perhitungan jumlah lampu UVC

\begin{tabular}{|l|l|}
\hline \multirow{5}{*}{ Tuntutan } & $\begin{array}{l}\text { Dosis UVC untuk mematikan } \\
\text { SARS-Cov-2 }=22 \mathrm{~mJ} / \mathrm{cm}^{2} \approx \\
\\
\end{array}$ \\
\hline & Luas lantai kelas $=64,08 \mathrm{~m}^{2}$ \\
\hline & Diketahui: \\
\hline
\end{tabular}

\begin{tabular}{|c|l|}
\hline \multirow{5}{*}{ Hitungan } & $\begin{array}{l}\text { Irradiasi }=0,09 \mathrm{~W} / \mathrm{m}^{2} \\
\text { Lama penyinaran } \mathrm{UVC}= \\
30 \text { menit } \approx 1800 \mathrm{~s}\end{array}$ \\
\cline { 2 - 2 } & $\begin{array}{l}\text { Persamaan dasar dosis UVC } \\
(\text { Juarez-Leon } \text { et al., 2020): } \\
\text { UVdose }\left(\mathrm{J} / \mathrm{cm}^{2}\right)= \\
\text { Irradiance }\left(\mathrm{W} / \mathrm{cm}^{2}\right) \text { x Times }(\mathrm{s})= \\
0,09 \mathrm{~W} / \mathrm{m}^{2} \mathrm{x} 1800 \mathrm{~s}=162 \mathrm{~J} / \mathrm{m}^{2}\end{array}$ \\
\cline { 2 - 2 } & $\begin{array}{l}\text { Dosis untuk ruang kelas }(\mathrm{x})= \\
220 \mathrm{~J} / \mathrm{m}^{2} \mathrm{x} 64,08 \mathrm{~m}^{2}=14.097,6 \mathrm{~J}\end{array}$ \\
& $\begin{array}{l}\text { Dosis lampu Philips pada satu } \\
\text { ruangan }(\mathrm{y})= \\
162 \mathrm{~J} / \mathrm{m}^{2} \mathrm{x} 64,08 \mathrm{~m}^{2}=10.380,96 \mathrm{~J}\end{array}$ \\
\cline { 2 - 2 } & $\begin{array}{l}\text { Jumlah lampu Philips yang } \\
\text { dibutuhkan }=\mathrm{x} / \mathrm{y}= \\
14.097,6 \mathrm{~J} / 10.380,96 \mathrm{~J} \approx 2\end{array}$ \\
\hline \multirow{2}{*}{ Hasil } & $\begin{array}{l}\text { Lampu Philips yang dibutuhkan } \\
\text { adalah sebanyak } 2 \text { buah. }\end{array}$ \\
\hline
\end{tabular}

Posisi penempatan lampu pada ruangan juga memengaruhi keberhasilan sterilisasi. Lampu UVC yang diletakkan pada langit-langit ruangan (ceilings) lebih efektif dalam sterilisasi ruangan dibandingkan lampu yang diletakkan pada tembok ruangan (Chitnis et al., 2008). Mengingat radiasi ultraviolet lampu ini dipancarkan terus menerus, tercapainya dosis yang dapat membunuh bakteri dalam ruangan bergantung pada durasi pemancaran (Song et al., 2020). Penyinaran selama 20-25 menit dinilai telah cukup untuk mendisinfeksi ruangan, tetapi durasi yang lebih dianjurkan adalah 30 menit (Chitnis et al., 2008). Berdasarkan pemaparan tersebut, perancangan smart classroom ini juga akan meletakkan kedua lampu UVC pada sisi kanan dan kiri langit-langit ruangan dengan durasi penyinaran selama 30 menit.

\subsection{Analisis Instrumentasi}

Simulasi sistem instrumentasi dilakukan dengan menggunakan Tinkercad. Sistem terdiri dari sistem kendali, sistem sensor, dan sistem aktuator. Sistem kendali terdiri dari Arduino Uno dan IC L293D, sedangkan sistem sensor terdiri dari dua buah sensor PIR yang berguna untuk entrance dan exit. Sementara itu, sistem aktuator terdiri dari motor servo pengunci pintu dan motor DC untuk buka-tutup pintu otomatis. Selain itu, output sistem juga terdiri dari UV light, lighting, lampu indikator, dan LCD. Rangkaian

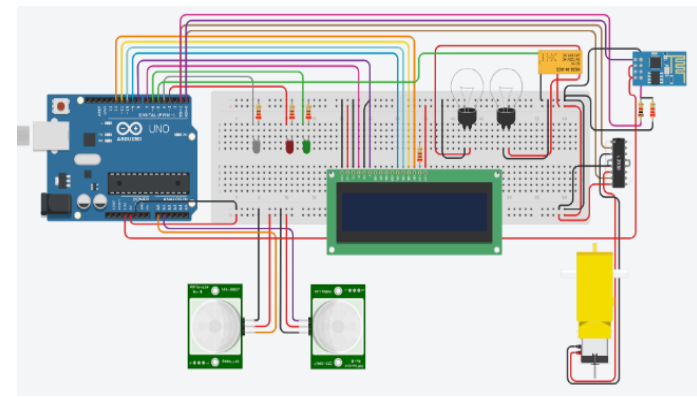

simulasi ditunjukkan pada Gambar 5. 
Gambar 5. Rangkaian sistem smart classroom

Pada perancangan yang dilakukan, PIR sensor digunakan sebagai touchless sensor yang berfungsi sebagai input untuk sistem buka-tutup pintu otomatis. Pada saat seseorang akan masuk ke dalam kelas maka ia dapat memberikan input kepada PIR sensor bagian entrance seperti dengan cara mengarahkan tangannya atau lainnya. Kemudian PIR sensor tersebut akan mendeteksi input yang diberikan dan membangkitkan sinyal yang dapat menjalankan sistem buka tutup pintu otomatis. Sistem buka tutup pintu tersebut bekerja dengan cara membuka pintu, lalu diam sejenak, dan menutup kembali sehingga orang selanjutnya yang akan masuk ke dalam kelas harus memberikan input PIR sensor kembali.

Setiap orang yang masuk maka akan dihitung sebagai 1 dan terus dijumlahkan untuk input-input selanjutnya. Begitu pula dengan PIR sensor bagian exit, tetapi tiap orang yang keluar akan dihitung sebagai -1 dan terus dijumlahkan untuk input-input selanjutnya. Jika hasil perhitungan menunjukkan sama dengan nol, maka hal itu menunjukkan bahwa semua orang di dalam kelas telah keluar. Kemudian sistem akan mematikan lighting, mengunci pintu secara otomatis, dan mengaktifkan UV untuk proses sterilisasi yang berjalan selama 30 menit. Pada saat proses sterilisasi dilakukan, maka lampu indikator merah akan menyala, sedangkan jika sedang tidak dilakukan proses sterilisasi, maka lampu undikator hijau akan menyala. Jika telah melewati waktu 30 menit, maka UV akan dimatikan, sedangkan lighting akan dihidupkan kembali dan kunci pintu akan terbuka.

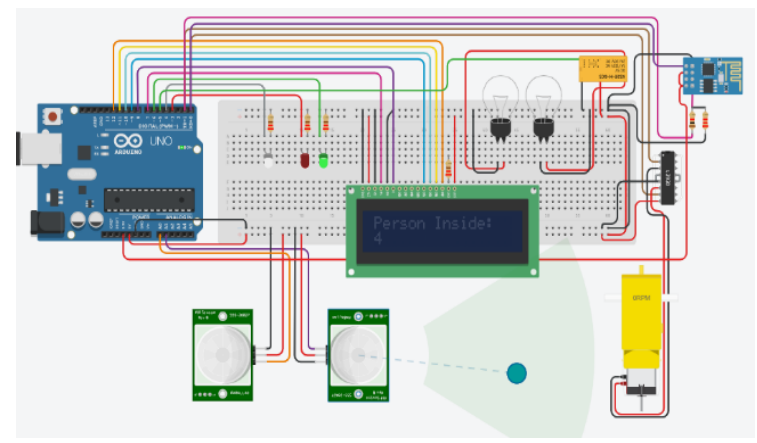

Gambar 6. Simulasi orang memasuki kelas

Sensor PIR counter+1 aktif dan memperlihatkan jumlah orang yang masuk ke dalam ruangan, serta lampu ruangan (putih) dan lampu indikator (hijau) menyala.

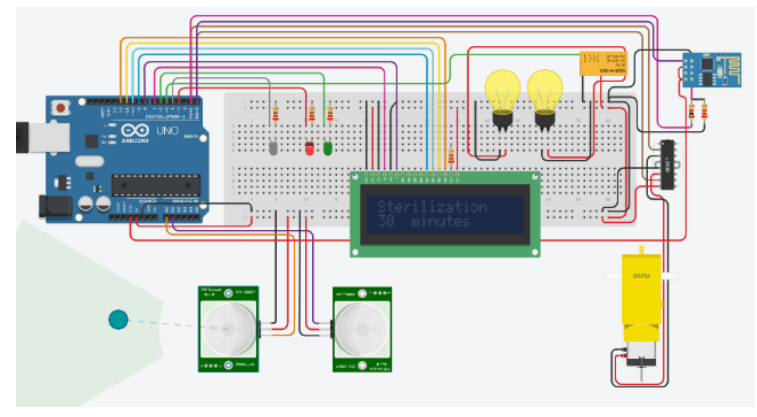

Gambar 7. Simulasi proses sterilisasi

Sensor PIR counter-1 aktif hingga mengakumulasi counter $=0$ dan menginisasi proses sterilisasi, serta 2 lampu UVC dan lampu indikator (merah) menyala.

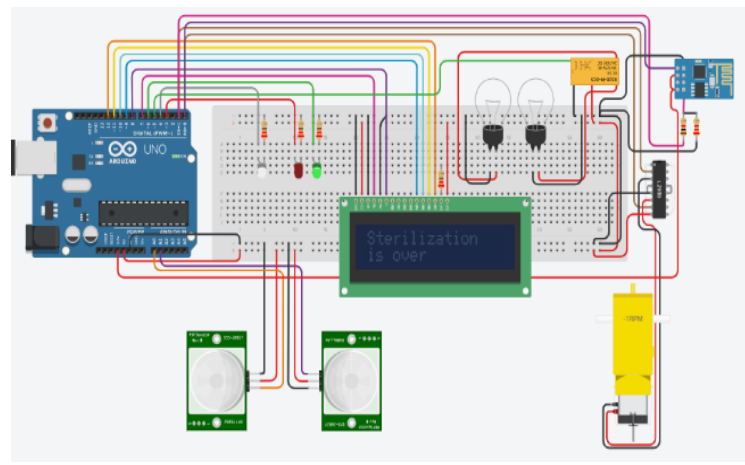

Gambar 8. Simulasi setelah proses sterilisasi

Setelah proses sterilisasi selama 30 menit berakhir, lampu ruangan dan lampu indikator (hijau) kembali menyala, serta sistem kembali seperti semula dan siklusnya akan terus beruptar (looping) selama 4 kali dalam sehari sesuai dengan jadwal yang telah ditentukan seperti yang ditunjukkan pada Tabel 2 .

Sistem instrumentasi smart classroom ini juga dirancang dengan sistem IoT untuk monitoring secara real time. Informasi proses yang terjadi akan dicatat dan dikirimkan ke monitor bagian sistem monitoring di suatu tempat dengan cara memanfaatkan modul WiFi dan webserver Thingspeak sehingga bagian operator dapat memantau proses yang terjadi. Simulasi real time monitoring dengan menggunakan webserver Thingspeak ditunjukkan pada Gambar 9. Pada gambar tersebut dapat dilihat bahwa jumlah orang di dalam kelas akan dipantau secara real time.

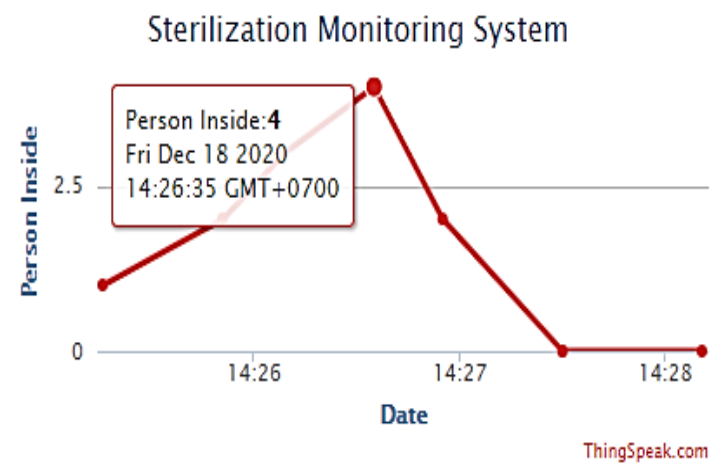

Gambar 9. Simulasi real time monitoring

Grafik hasil simulasi ditampilkan menggunakan Thingspeak untuk memantau jumlah orang di dalam ruangan. Ketika jumlah orang di dalam ruangan $=0$, proses sterilisasi sedang berlangsung. Skema utuh sistem dalam menjalankan proses steriliasi untuk ruang kelas terdapat pada Gambar 10. 


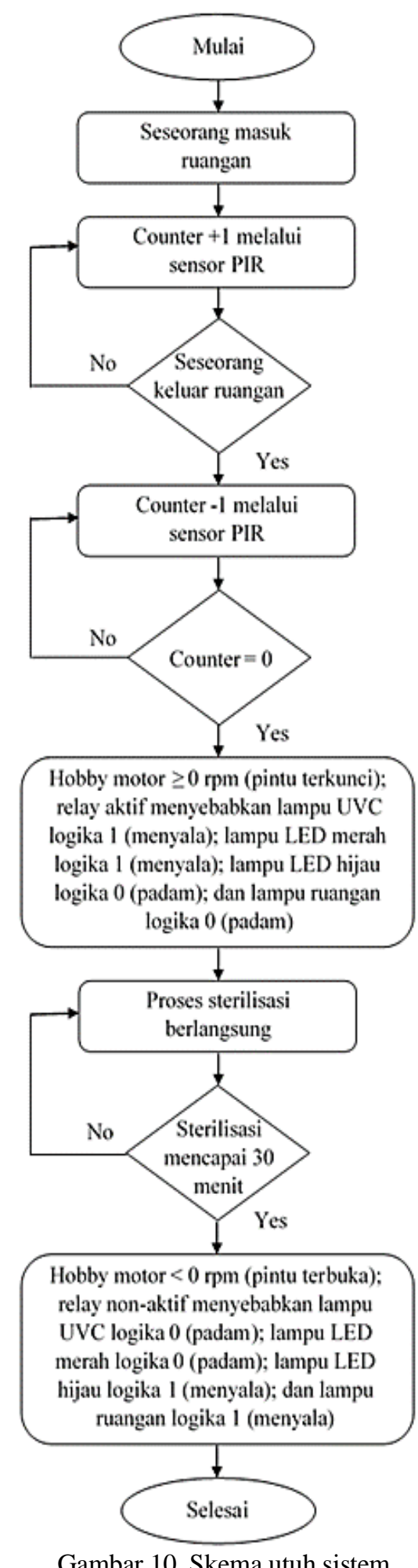

Gambar 10. Skema utuh sistem

Hasil simulasi dapat diakses pada link berikut:

- Simulasi instrumentasi dan kode pemrograman: https://www.tinkercad.com/things/9mXNOLMNlvl

- Website Interface (Sistem IoT): https://parakarta.weebly.com/

\section{Kesimpulan}

Smart sterilization system dirancang untuk mempersiapkan kegiatan belajar mengajar di era new normal pandemi Covid-19 agar berjalan dengan aman dan nyaman. Inovasi yang dirancang yaitu berupa smart classroom yang dilengkapi dengan sistem sterilisasi berupa sinar UVC dengan panjang gelombang $254 \mathrm{~nm}$ dan lama penyinaran selama 30 menit. Berdasarkan perhitungan, diperlukan lampu tipe TMS030-1xTUV-T8-18W-HFP yang diproduksi oleh Philips sebanyak 2 buah untuk suatu ruang kelas dengan luas 64,08 $\mathrm{m}^{2}$. Perancangan dan pengujian sistem dilakukan secara simulasi menggunakan Tinkercad dan Thingspeak. Sistem yang dirancang juga dilengkapi dengan sistem keamanaan berupa pengunci otomatis, touchless sensor untuk membuka dan menutup pintu, pencahayaan otomatis, dan sistem monitoring berbasis IoT (Internet of Things) dengan memanfaatkan web server Thingspeak dan modul WiFi ESP8266. Smart sterilization system memiliki potensi hasil yang besar dalam mencegah persebaran Covid-19 melalui analisis dosis yang tepat untuk menginaktivasi Sars-CoV-2 dengan diimplementasikan melalui banyaknya jumlah lampu UVC yang digunakan, serta menciptakan lingkungan sehat untuk menunjang kegiatan belajar mengajar (KBM) di dalam kelas selama masa new normal.

\section{Daftar Pustaka}

Anuradha, R., Bharathi, R., Karthika, K., Kirithika, S., \& Venkatasubramanian, S. (2016). Anuradha.R.S, Bharathi.R, Karthika.K, Kirithika.S, and S.Venkatasubramanian; "Optimized Door Locking and Unlocking Using IoT for Physically Challenged Peopl. International Journal of Innovative Research in Computer and Communication Engineering, 4(3).

Arinda, I.D., 2015. Pengaruh Daya Dan Lama Penyinaran Sinar Ultraviolet-C Terhadap Total Mikroba Sari Buah Salak Pondoh 3, 8.

Bianco, A., Biasin, M., Pareschi, G., Cavalleri, A., Cavatorta, C., Fenizia, C., Galli, P., Lessio, L., Lualdi, M., Redaelli, E., Saulle, I., Trabattoni, D., Zanutta, A., Clerici, M. (2020). UV-C irradiation is highly effective in inactivating and inhibiting SARS-CoV-2 replication. https://doi.org/10.1101/2020.06.05.20123463.

Casini, B., Tuvo, B., Cristina, M. L., Spagnolo, A. M., Totaro, M., Baggiani, A., \& Privitera, G. P. (2019). Evaluation of an Ultraviolet C (UVC) Light-Emitting Device for Disinfection of High Touch Surfaces in Hospital Critical Areas. International Journal of Environmental Research and Public Health, 16(19), 3572. https://doi.org/10.3390/ijerph16193572

Chitnis, D., Katara, G., Hemvani, N., Chitnis, S., \& Chitnis, V. (2008). Surface Disinfection by Exposure to Germicidal UV Light. Indian Journal 
of Medical Microbiology, 26(3), 241. https://doi.org/10.4103/0255-0857.42034

Darnell, M. E. R., Subbarao, K., Feinstone, S. M., \& Taylor, D. R. (2004). Inactivation of The Coronavirus That Induces Severe Acute Respiratory Syndrome, SARS-CoV. Journal of Virological Methods, 121(1), 85-91. https://doi.org/10.1016/j.jviromet.2004.06.006

Dwi Elisanti, A., \& Ardianto, E. (2020). Efektivitas Paparan Sinar UV dan Alkohol 70\% terhadap Total Bakteri pada Uang Kertas yang Beredar di Masa Pandemi Covid-19. Jurnal Riset Kefarmasian Indonesia, 2, 202. https://doi.org/10.33759/jrki.v2i2.88

Fauzan, M.I. (2015). Automation System Design for Stopper Valve Chamfering Process On Bench Lathe SD-32A Machine at PT. Dharma Precision Parts, Bandung: Telkom University.

Gugus Tugas Percepatan Penanganan Covid-19, "Peta Sebaran," 2021. [Online]. Available: https://COVID19.go.id/peta- sebaran. [Diakses 17 April 2021].

Hakim, L.A., \& Anugraha R.A. (2017), Perancangan Sistem Otomasi Proses Pelubangan Kartu Tekstil Jacquard pada Mesin Punching di PT. Buana Intan Gemilang. Jurnal Rekayasa Sistem \& Industri, 4(1).

Ika. (2020). AC Bisa Tingkatkan Risiko Infeksi Covid19? Universitas Gadjah Mada.

Isfardiyana, S. H., \& Safitri, S. R. (2014). Pentingnya Melindungi Kulit dari Sinar Ultraviolet dan Cara Melindungi Kulit dengan Sunblock Buatan Sendiri. Jurnal Inovasi dan Kewirausahaan, 3(2), 8.

Iswanto \& Gandi (2018). Perancangan dan Implementasi Sistem Kendali Lampu Ruangan Berbasis IoT (Internet of Things) Android (Studi Kasus Universitas Nurtanio). Jurnal Teknologi Informasi dan Komunikasi, 9(1).

Juarez-Leon, F. A., Soriano-Sanchez, A. G., Rodriguez-Licea, M. A., \& Perez-Pinal, F. J. (2020). Design and Implementation of a Germicidal UVC-LED Lamp. IEEE Access, 8, 196951-196962.

https://doi.org/10.1109/ACCESS.2020.3034436

Kompas.com, "Kuliah Tatap Muka Bisa Dimulai Juli 2021, Ini Penjelasan Ditjen Dikti,” 9 Maret 2021. [Online]. Available:

https://www.kompas.com/tren/read/2021/03/09/1 33802465/kuliah-tatap-muka-bisa-dimulai-juli2021-ini-penjelasan-ditjen-dikti?page $=$ all. [Diakses 10 Maret 2021].

Lee, L. D. (2017). Surface and air: What impact does UV-C at the room level have on airborne and surface bacteria? Canadian Journal of Infection Control, 32(2), 4.

Muvianto, C. M. O., \& Yuniarto, K. (2020). Pemanfaatan UV-C Chamber Sebagai Disinfektan Alat Pelindung Diri Untuk Pencegahan Penyebaran Virus Corona. Abdi
Insani, 7(1), 87-92. https://doi.org/10.29303/abdiinsani.v7i1.312

Philips. (2006). Ultraviolet Purification Application Information. Philips.

Philips. (2020). Datasheet Philips UV-C Batten the Power to Protect. Philips.

Prasetio, E., \& Hendriyani, Y. (2019). Pengembangan Sistem Informasi dan Aplikasi Pe layanan Di UPT Balai Bahasa UNP Berbasis Android. Jurnal Vokasional Teknik Elektronika dan Informatika, 166-174.

Prastyowati, A. (2020). Mengenal Karakteristik Virus SARS-CoV-2 Penyebab Penyakit COVID-19 Sebagai Dasar Upaya Untuk Pengembangan Obat Antivirus dan Vaksin. 10.

Pristianto, E.J., Wijayanto, Y.N., Kurniawan, D., Arisesa, H., \& Prawara, B. (2020). Sistem Kendali Alat Sterilisasi Ruangan Menggunakan Lampu UVC254 Nm dengan Android 7.

Raudah, R., Zubaidah, T., \& Santoso, I. (2017). Efektivitas Sterilisasi Metode Panas Kering pada Alat Medis Ruang Perawatan Luka Rumah Sakit dr. H. Soemarno Sosroatmodjo Kuala Kapuas. Jurnal Kesehatan Lingkungan: Jurnal dan Aplikasi Teknik Kesehatan Lingkungan, 14(1), 425. https://doi.org/10.31964/jkl.v14i1.56

Rinaldi, R. S., \& Anggraini, I. N. (2021). Perancangan Sistem Disinfektan UV-C Sterlisasi Paket sebagai Pencegahan Penyebaran Covid-19. Jurnal Nasional Teknik Elektro dan Teknologi Informasi, l(1), 61.

Seran, Y. Y. T., Pasangka, B., \& Sutaji, H. I. (2018). Karakteristik Paparan Radiasi Sinar Ultraviolet A (UV-A) dan Cahaya Tampak di Kota Kupang. Jurnal Biotropikal Sains, 15(3), 8.

Shereen MA, Khan S, Kazmi A, Bashir N, and Siddique R. (2020). Covid-19 Infection: Origin, Transmission, and Characteristics of Human Coronaviruses. Journal of Advanced Research, 24, 91-98. doi:10.1016/j.jare. 2020.03.0 05.

Spencer, M., Vignari, M., Bryce, E., Johnson, H. B., Fauerbach, L., \& Graham, D. (2017). A Model for Choosing an Automated Ultraviolet-C Disinfection System and Building A Case for the C-suite: Two Case Reports. American Journal of Infection Control, 45(3), 288-292. https://doi.org/10.1016/j.ajic.2016.11.016

Song, L., Li, W., He, J., Li, L., Li, T., Gu, D., \& Tang, H. (2020). Development of a Pulsed Xenon Ultraviolet Disinfection Device for Real-Time Air Disinfection in Ambulances. Journal of Healthcare Engineering, 1-5. https://doi.org/10.1155/2020/6053065

Susilo, A., Rumende, C. M., Pitoyo, C. W., Santoso, W. D., \& Yulianti, M. (2020). Coronavirus Disease 2019: Tinjauan Literatur Terkini. Jurnal Penyakit Dalam Indonesia, 7(1).

Suwantoro, A., \& Samsugi, S. (2018). Pemanfaatan Peltier dan Heater sebagai Alat Pengontrol Suhu 
Air pada Bak Penetasan Telur Ikan Gurame. Conf. Inf. Technol, 295-299.

Waworundeng, J., Irawan, L.D., \& Pangalila, A. (2017). Implementasi Sensor PIR sebagai Pendeteksi Gerakan untuk Sistem Keamanan Rumah menggunakan Platform IoT. Jurnal CogITo Smart, 3(2), 152.

WHO, "Coronavirus disease 2019 (COVID-19) Situation Report," World Health Organization, 2020.

World Health Organization. (2020). Pembersihan dan Disinfeksi Permukaan Lingkungan dalam Konteks COVID-19," Panduan Interim

World Health Organization (WHO). (2020). Transmisi SARS-CoV-2: Implikasi Terhadap Kewaspadaan Pencegahan Infeksi. Pernyataan Keilmuan

Worldometer, "Reported Cases and Deaths by Country or Territory," 16 April 2021. [Online]. Available: https://www.worldometers.info/coronavirus/?utm _campaign=homeAdvegas1?\%22. [Diakses 17 April 2021].

Yulianto, T. B., Taufiq, A. J., \& Suyadi, A. (2019). Rancang Bangun Pengaturan Intensitas Sinar UV (Ultraviolet) dengan Mikrokontroler PIC untuk Tanaman. Jurnal Riset Rekayasa Elektro, 1(1). https://doi.org/10.30595/jrre.v1i1.4929 